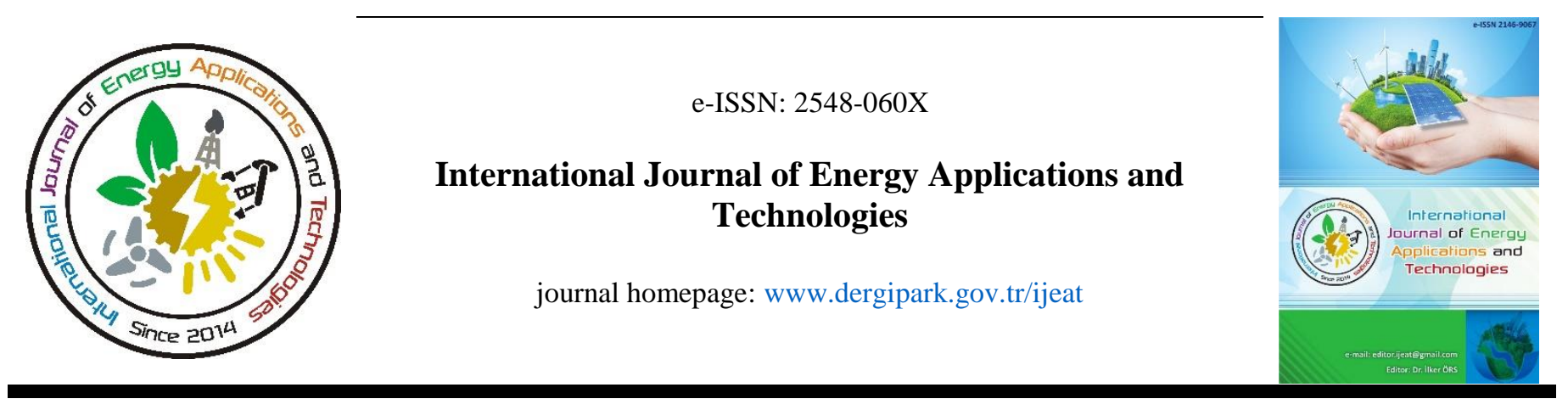

Original Research Article

\title{
Comparative exergy analysis of the cascade cooling system for alternative refrigerant couples
}

\author{
Erkan Dikmen*, Arzu Şencan Şahin \\ Isparta University of Applied Sciences, Technology Faculty, Mechanical Engineering Department 32260, Isparta, Turkey
}

\author{
ARTICLE INFO \\ * Corresponding author \\ erkandikmen@isparta.edu.tr \\ Received July 21, 2020 \\ Accepted October 12, 2020 \\ Published by Editorial Board \\ Members of IJEAT \\ (C) This article is distributed by \\ Turk Journal Park System under \\ the CC 4.0 terms and conditions. \\ doi: $10.31593 /$ ijeat. 772180
}

\begin{abstract}
In this work, a comparative exergy analysis of cascade cooling system working with alternative refrigerant couples has been carried out. In study; R454C and R-744 as low temperature cycle (LTC) refrigerant and R1234ze, R1234yf and R717 as high temperature cycle (HTC) refrigerant were used. The refrigerants used in the study have zero ODP and low GWP values. Exergy analysis was carried out to investigate the effect to exergy efficiency of operation parameters in cascade cooling system. The exergy efficiency values of the cascade cooling system decreases with increasing evaporator temperature for all refrigerant couples. The exergy efficiency values of the cascade cooling system decreases with increasing the condenser temperature. Obtained results show that in all cases, the refrigerant couple R454C/R717 has the highest exergy efficiency.
\end{abstract}

Keywords: Cascade cooling system; Exergy; Refrigerant; Thermodynamic analysis

\section{Introduction}

To use a single stage cooling system in low temperature applications is not economical. Cascade cooling systems can be used for these applications [1]. Cascade cooling system consists of two cycles, low temperature (LTC) and high temperature cycle (HTC). In addition, it is important that the refrigerant couples used in these systems are environmentally friendly and not harmful to the environment. Many studies on energy and exergy analysis of cascade cooling systems operating with different refrigerant couples are available in literature. Sun et al. performed energy and exergy analysis of cascade cooling system with low GWP refrigerants. The effect of system parameters, such as evaporator temperature and condenser temperature, on the system performance was investigated [1]. Gholamian et al. performed modeling of a carbon dioxide ammonia cascade cooling system. Advanced exergy analysis was applied to the system [2]. Kilicarslan and Hosoz carried out energy and exergy analysis of a cascade cooling system by using different refrigerant couples [3]. Roy and Mandal performed exergy analysis of cascade cooling system operating with refrigerant couples R41R404A and R41-R161. Obtained results present that R41R161 gives better results than R41 - R404A [4]. Kanoğlu carried out exergy analysis of cascade cooling cycle used for natural gas liquefaction. The exergy efficiency of the multistage cascade cooling cycle is determined to be $38.5 \%$ [5]. Dopazo et al. investigated performance and exergy efficiency of cascade cooling system with $\mathrm{CO}_{2}-\mathrm{NH}_{3}$. Moreover, an optimization study was performed [6]. Rezayan and Behbahaninia carried out optimization and exergy analysis of cascade cooling system with $\mathrm{CO}_{2}-\mathrm{NH}_{3}$ [7]. The other studies on cascade cooling systems are available in literature [8-17].

In this work, exergy analysis of the cascade cooling system was carried out using alternative refrigerants with zero ODP and low GWP values as different from the literature. Depending on the different operating parameters of the 
system, exergy efficiencies were examined. Comparative exergy analysis of the cascade cooling system using different refrigerant couples was made using EES (Engineering Equation Solver) [18].

\section{Thermodynamic Analysis}

Fig. 1 shows schematic diagram of cascade cooling system. Cascade cooling system occurs of low temperature cycle (LTC) and high temperature cycle (HTC). Fig. 2 shows T-s diagrams of cascade cooling system.

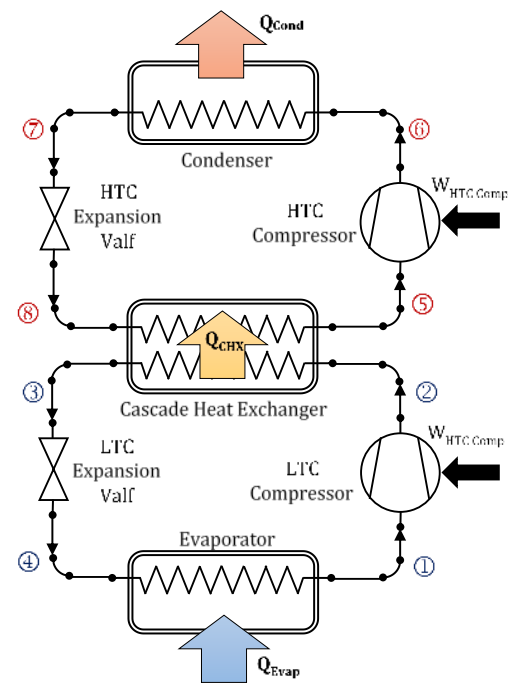

Fig. 1. Schematic diagram of cascade cooling system

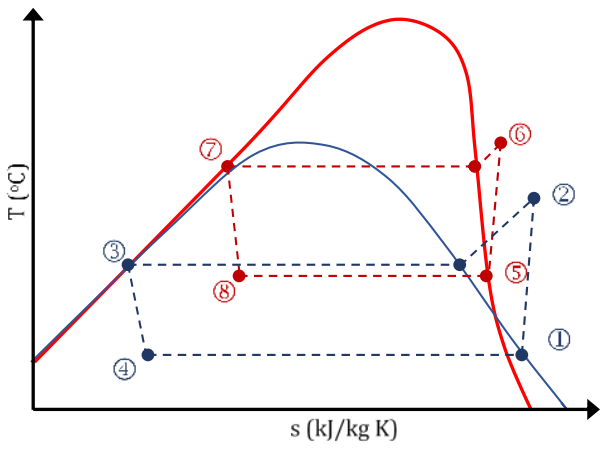

Fig. 2. T-s diagram of cascade cooling system.

Refrigerant couples used in LTC and HTC and their properties are given in Table 1.

Table 1. Thermo physical Properties of refrigerants

\begin{tabular}{|c|c|c|c|c|c|c|}
\hline & Refrigerant & $\begin{array}{l}\text { Boiling } \\
\text { Point } \\
\left({ }^{\circ} \mathrm{C}\right) \\
\end{array}$ & $\begin{array}{c}\text { Critical } \\
\text { Temperature } \\
\left({ }^{\circ} \mathrm{C}\right)\end{array}$ & $\begin{array}{c}\text { Critical } \\
\text { Pressure } \\
\text { (bar) }\end{array}$ & ODP & GWP \\
\hline \multirow{2}{*}{$\begin{array}{l}\mathrm{L} \\
\mathrm{T} \\
\mathrm{C}\end{array}$} & $\mathrm{R}-454 \mathrm{C}$ & $\begin{array}{c}- \\
45.91\end{array}$ & 82.40 & 43.50 & 0 & 146 \\
\hline & R-744 & $\begin{array}{c}- \\
78.40\end{array}$ & 31.10 & 73.17 & 0 & 1 \\
\hline \multirow{3}{*}{$\begin{array}{l}\mathrm{H} \\
\mathrm{T} \\
\mathrm{C}\end{array}$} & R-1234ze & 18.98 & 108.0 & 35.39 & 0 & 1 \\
\hline & R-1234yf & $\begin{array}{c}- \\
29.49\end{array}$ & 94.70 & 32.69 & 0 & 1 \\
\hline & $\mathrm{R}-717$ & $\begin{array}{c}- \\
33.30\end{array}$ & 132.30 & 113.30 & 0 & 0 \\
\hline
\end{tabular}

The following assumptions were made in the thermodynamic analysis.

- Heat losses and pressure drops in the system components are neglected.

- All the components are at steady state condition.

- Cooling capacity of the system is accepted as 15 $\mathrm{kW}$.

- No subcooling and superheating is considered.

- The enthalpy is constant in the throttling process in the throttling valves in HTC and LTC cycles.

- The compression in HTC and LTC is isentropic.

- Ambient temperature is $25^{\circ} \mathrm{C}$.

Based on the above assumptions, balance equations are written to obtain the mass flow rate, the compressor work, the heat transfer rates and the exergy destruction rate as follows:

Mass balance:

$$
\sum \dot{m}_{l}=\sum \dot{m}_{o}
$$

Energy balance:

$$
\dot{Q}-\dot{W}=\sum \dot{m}_{\mathrm{o}}\left(h_{\mathrm{o}}+\frac{V_{\mathrm{o}}^{2}}{2}\right)-\sum \dot{m}_{l}\left(h_{\mathrm{i}}+\frac{V_{i}^{2}}{2}\right)
$$

Exergy balance:

$$
\sum E D=\sum \dot{E x}_{\mathrm{i}}-\sum \dot{E x_{0}}
$$

Energy and exergy balance equations of cascade cooling system are given in Table 2 .

Total exergy destruction of the system and can be written as:

$E D_{\text {total }}=E D_{\text {HTC comp }}+E D_{\text {Cond }}+E D_{H T C E V}+E D_{C H X}$

$+E D_{\text {LTC comp }}+E D_{L T C E V}+E D_{\text {Cond }}$

The coefficient of performance (COP) can be defined as:

$$
C O P=\frac{Q_{E}}{W_{H T C}+W_{L T C}}
$$

Exergetic efficiency of cascade cooling system can be written as:

$\eta_{e x}=\frac{W_{H T C}+W_{L T C}-E D_{\text {total }}}{W_{H T C}+W_{L T C}}$

\section{Results and Discussion}

Exergy analysis of the cascade cooling system using R454C and R-744 as LTC refrigerant and R1234ze, R1234yf and R717 as HTC refrigerant has been carried out. Fig. 3 shows the variation in the exergy efficiency of the refrigerant couples with evaporator and condenser temperature. In Fig. 3 , it is seen that the exergy efficiency decreases with the increase of the evaporator temperature and the exergy efficiency decreases with the increase of the condenser temperature in the cascade cooling system operating with all refrigerant couples. 
Table 2. Energy and exergy balance equations of cascade cooling system

\begin{tabular}{l|l|l}
\hline \multicolumn{1}{c|}{ Component } & \multicolumn{1}{c}{ Energy balance } & \multicolumn{1}{c}{ Exergy balance } \\
\hline HTC compressor & $W_{H T C \text { comp }}=m_{H}\left(h_{6}-h_{5}\right)$ & $E D_{H T C \text { comp }}=T_{0} m_{H T C}\left(s_{6}-s_{5}\right)$ \\
Condenser & $Q_{\text {Cond }}=m_{H T C}\left(h_{6}-h_{7}\right)$ & $E D_{\text {Cond }}=T_{0} m_{H T C}\left(s_{7}-s_{6}\right)+Q_{\text {Cond }}$ \\
HTC expansion value & $h_{7}=h_{8}$ & $E D_{H T C ~ E V}=T_{0} m_{H T C}\left(s_{8}-s_{7}\right)$ \\
Cascade heat exchanger & $Q_{C H X}=m_{L T C}\left(h_{2}-h_{3}\right)=m_{H T C}\left(h_{5}-h_{8}\right)$ & $E D_{C H X}=T_{0}\left[m_{L T C}\left(s_{3}-s_{2}\right)+m_{H T C}\left(s_{5}-s_{8}\right)\right]$ \\
LTC compressor & $W_{L T C \text { comp }}=m_{L T C}\left(h_{2}-h_{3}\right)$ & $E D_{L T C \text { comp }}=T_{0} m_{L T C}\left(s_{2}-s_{1}\right)$ \\
LTC expansion value & $h_{3}=h_{4}$ & $E D_{L T C E V}=T_{0} m_{L T C}\left(s_{4}-s_{3}\right)$ \\
LTC evaporator & $Q_{E v a p}=m_{L T C}\left(h_{1}-h_{4}\right)$ & $E D_{\text {Cond }}=T_{0} m_{L T C}\left(s_{1}-s_{4}\right)+Q_{E v a p}$ \\
\hline
\end{tabular}
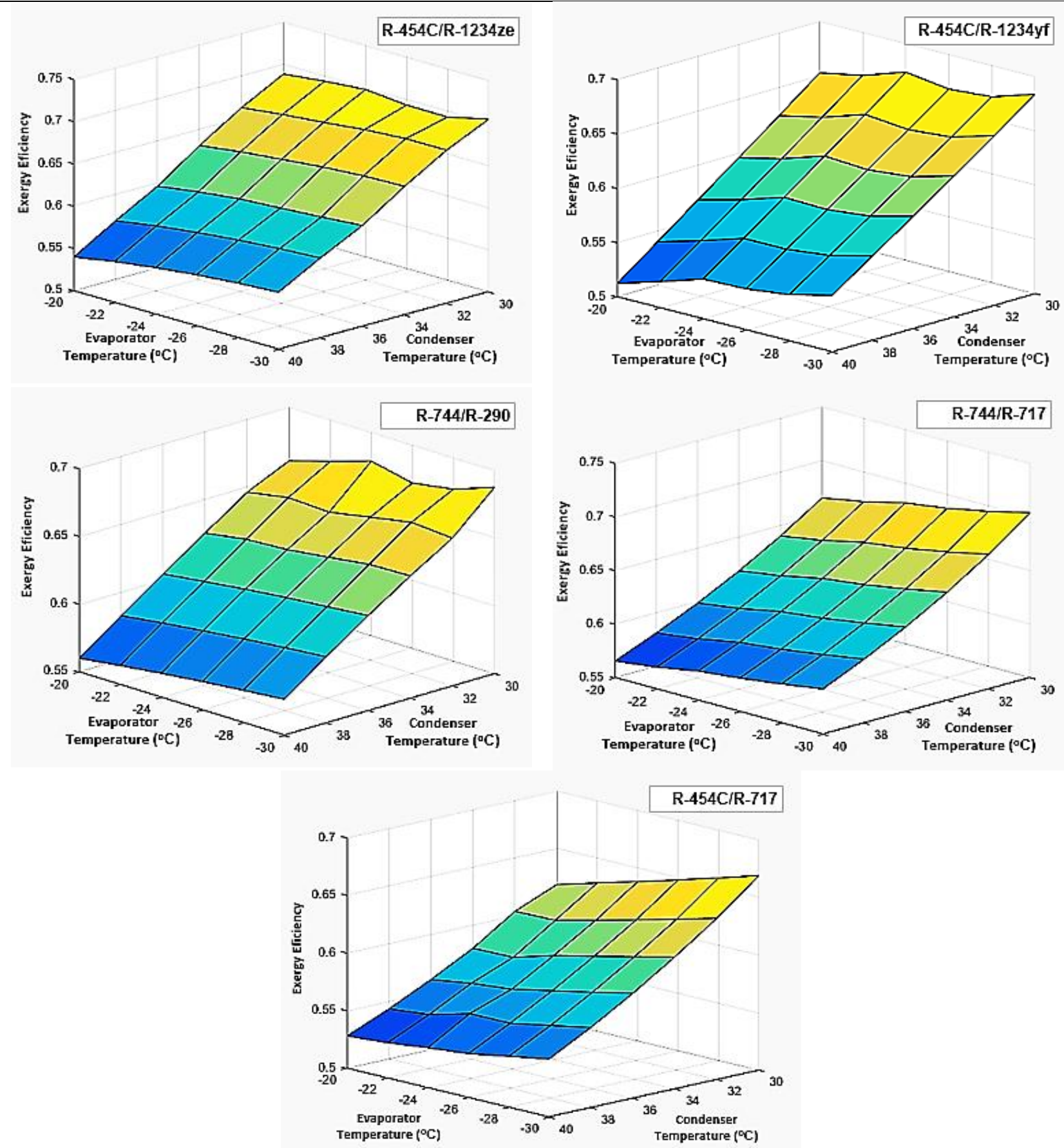

Fig.3. Variation of exergy efficiency with condenser and evaporator temperatures for different refrigerant couples 
Fig.4 shows the effect of evaporator temperature on exergy efficiency in cascade cooling system using different refrigerant couples. By keeping the condenser temperature constant at $40^{\circ} \mathrm{C}$, the exergy efficiencies were calculated by changing the evaporator temperature values in the LTC from $-30^{\circ} \mathrm{C}$ to $-20^{\circ} \mathrm{C}$. Exergy efficiency of the system for all refrigerant couples decreased with the increase of evaporator temperature. The exergy efficiency of the system operating with R454C / R717 was found to be higher than the exergy efficiency values of the system working with other refrigerant couples. The lowest exergy efficiency for the same operating parameters was found to be 0.51 in the system operating with the R454C / R1234yf. The highest exergy efficiency was found as 0.59 in the system working with R454C / R717.

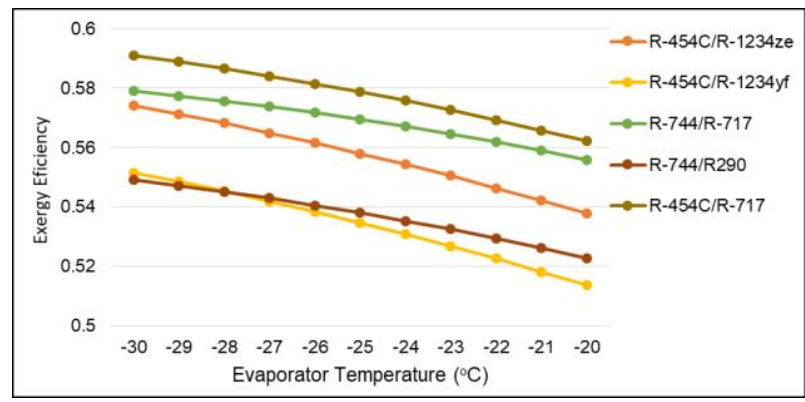

Fig.4. Comparison of the impact of evaporator temperature on exergy efficiency value for alternative refrigerant couples

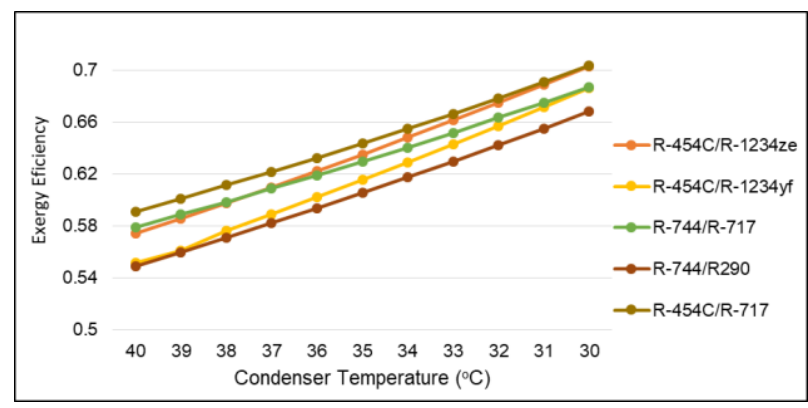

Fig.5. Comparison of the impact of condenser temperature on exergy efficiency value for alternative refrigerant couples

In Fig. 5, the variation of exergy efficiencies with the condenser temperature is given in a cascade cooling system operating with different refrigerant couples. Exergy efficiency value was calculated by changing the condenser temperature values between $30^{\circ} \mathrm{C}$ and $40^{\circ} \mathrm{C}$ by keeping the evaporator temperature constant at $-30^{\circ} \mathrm{C}$. Exergy efficiency of the system for all refrigerant couples decreased with increasing condenser temperature. The exergy efficiency of the system by working with R454C / R717 refrigerant couple was found to be higher than the exergy efficiency of the system working with other refrigerant couples. The lowest exergy efficiency for the same operating parameters was found to be 0.55 in the system operating with the R744 / R290 refrigerant couple. The highest exergy efficiency value was found as 0.7 in the system working with R454C / R717 refrigerant couple.

\section{Conclusions}

The negative effects of refrigerants used in cooling systems on the environment are great. Many efforts are made to develop alternative refrigerant pairs suitable for low GWP and high efficiency cascade cooling systems.

In this work, exergy analysis of the cascade cooling system working with R454C and R-744 as LTC refrigerant and R1234ze, R1234yf and R717 as HTC refrigerant with zero ODP value and low GWP value was performed. Analyzes were made using the EES program. It has been observed that the exergy efficiency values of the system working with $\mathrm{R} 454 \mathrm{C}$ in the LTC cycle and the R717 refrigerant couple in the HTC cycle are higher than the exergy efficiency values of the system working with other refrigerant couples. The lowest exergy efficiency value for the same operating parameters was found to be 0.51 in the system operating with the R454C / R1234yf refrigerant couple. The highest exergy efficiency value was found to be 0.7 in the system working with R454C / R717 refrigerant couple.

\section{ORCID}

Erkan Dikmen

Arzu Ş. Şahin

$0000-0002-6804-8612$

0000-0001-8519-4788

\section{References}

[1] Sun, Z., Wang, Q., Xie, Z., Liu, S., Su, D. and Cui, Q. 2019. Energy and exergy analysis of low GWP refrigerants in cascade refrigeration system. Energy, 170, 1170-1180. Doi: 10.1016/j.energy.2018.12.055

[2] Gholamian, E., Hanafizadeh, P. and Ahmadi, P. 2018. Advanced exergy analysis of a carbon dioxide ammonia cascade refrigeration system. Appl. Therm. Eng., 137, 689-699. Doi: 10.1016/j.applthermaleng. 2018.03.055

[3] Kilicarslan, A. and Hosoz, M. 2010. Energy and irreversibility analysis of a cascade refrigeration system for various refrigerant couples. Energy Convers. Manage., $51 \quad$ (12), 2947-2954. Doi:10.1016 /j.enconman.2010.06.037

[4] Roy, R. and Mandal, B.K. 2018. Exergy analysis of cascade refrigeration system working with refrigerant pairs R41-R404A and R41-R161. In IOP Conf. Ser., Mater. Sci. Eng., 377 (1), 012036. Doi:10.1088/1757899X/377/1/012036

[5] Kanoğlu, M. 2002. Exergy analysis of multistage cascade refrigeration cycle used for natural gas liquefaction. Int. J. Energy Res., 26 (8),763-774. Doi:10.1002/er.814

[6] Dopazo, J.A., Fernández-Seara, J., Sieres, J. and Uhía, F.J. 2009. Theoretical analysis of a $\mathrm{CO}_{2}-\mathrm{NH}_{3}$ cascade refrigeration system for cooling applications at low temperatures, Appl. Therm. Eng., 29 (8-9), 1577-1583. Doi: 10.1016/j.applthermaleng.2008.07.006 
[7] Rezayan, O. and Behbahaninia, A. 2011. Thermoeconomic optimization and exergy analysis of $\mathrm{CO}_{2} / \mathrm{NH}_{3}$ cascade refrigeration systems. Energy, 36 (2), 888-895. Doi: 10.1016/j.energy.2010.12.022

[8] Lee, T.S., Liu, C.H. and Chen T.W. 2006. Thermodynamic analysis of optimal condensing temperature of cascade-condenser in $\mathrm{CO}_{2} / \mathrm{NH}_{3}$ cascade refrigeration systems, Int. J. Refrig., 29 (7), 1100-1108. Doi: 10.1016/j.ijrefrig.2006.03.003

[9] Getu, H.M. and Bansal, P.K. 2008. Thermodynamic analysis of an R744-R717 cascade refrigeration system, Int. J. Refrig., 31 (1), 45-54. Doi: 10.1016 /j.ijrefrig.2007.06.014

[10] Bingming, W., Huagen, W., Jianfeng, L. and Ziwen, X. 2008. Experimental investigation on the performance of $\mathrm{NH}_{3} / \mathrm{CO}_{2}$ cascade refrigeration system with twin-screw compressor. Int. J. Refrig., 32 (6), 1358-1365. Doi: 10.1016/j.ijrefrig.2009.03.008

[11] Dopazo, J.A. and Fernández-Seara, J. 2010. Experimental evaluation of a cascade refrigeration system prototype with $\mathrm{CO}_{2}$ and $\mathrm{NH}_{3}$ for freezing process applications. Int. J. Refrig., 34 (1), 257-267. Doi: 10.1016/j.ijrefrig.2010.07.010

[12] Cabello, R., Sánchez, D., Llopis, R., Catalán, J., NebotAndrés, L. and Torrella, E. 2017. Energy evaluation of $\mathrm{R} 152 \mathrm{a}$ as drop in replacement for R134a in cascade refrigeration plants. Appl. Therm. Eng., 110, 972-984. Doi: 10.1016/j.applthermaleng.2016.09.010

[13] Eini, S., Shahhosseini, H., Delgarm, N., Lee, M. and Bahadori, A. 2016. Multi-objective optimization of a cascade refrigeration system: exergetic, economic, environmental and inherent safety analysis, Appl. Therm. Eng., 107, 804-817. Doi: 10.1016/j.applthermaleng. 2016.07.013

[14] Llopis, R., Sanz-Kock, C., Cabello, R., Sánchez, D., Nebot-Andrés, L. and Catalán-Gil, J. 2016. Effects caused by the internal heat exchanger at the low temperature cycle a cascade refrigeration plant. Appl. Therm. Eng., 103, 1077-1086. Doi: 10.1016/j.applthermaleng .2016.04.075

[15] Mosaffa, A.H., Farshi, L.G., Infante Ferreira, C.A. and Rosen, M.A. 2016. Exergoeconomic and environmental analyses of $\mathrm{CO}_{2} / \mathrm{NH}_{3}$ cascade refrigeration systems equipped with different types of flash tank intercoolers. Energy Convers. Manage., 117, 442-453. Doi: 10.1016 /j.enconman.2016.03.053

[16] Queiroz, M.V.A., Panato, V.H., Antunes, A.H.P., Parise, J.A.R. and Bandarra Filho, E.P. 2016. Experimental comparison of a cascade refrigeration system operating with R744/R134a and R744/R404a. 16th International Refrigeration and Air Conditioning Conference (July 11 -14 Purdue Conferences). USA. 1785-1795. http://docs.lib.purdue.edu/iracc/1785

[17] Dikmen, E., Şahin, A.Ş., Deveci, Ö.İ. and Akdağ, E. 2020. GWP Değeri Düşük Soğutucu Akışkanların Kullanıldığı Kaskad Soğutma Sisteminin
Karşılaştırmalı Performans Analizi. ECSJE, 7(1), 338345. Doi: /10.31202/ecjse. 630262

[18] Engineering Equation Solver (EES) software, 10.614 Academic version, 2019. 